\title{
Correction to: Diauxic Inhibition: Jacques Monod's Ignored Work
}

\author{
Pierre Louis Blaiseau ${ }^{1}$ - Allyson M. Holmes ${ }^{1}$
}

Accepted: 1 July 2021 / Published online: 13 July 2021

(c) Springer Nature B.V. 2021

\section{Correction to: Journal of the History of Biology https://doi.org/10.1007/s10739-021-09639-4}

The article "Diauxic Inhibition: Jacques Monod's Ignored Work", written by Pierre Louis Blaiseau and Allyson M. Holmes, was originally published electronically on the publisher's internet portal on 11 May 2021 without open access. With the author(s)' decision to opt for Open Choice the copyright of the article changed on 15 June 2021 to (C) The Author(s) 2021 and the article is forthwith distributed under a Creative Commons Attribution 4.0 International License, which permits use, sharing, adaptation, distribution and reproduction in any medium or format, as long as you give appropriate credit to the original author(s) and the source, provide a link to the Creative Commons licence, and indicate if changes were made. The images or other third party material in this article are included in the article's Creative Commons licence, unless indicated otherwise in a credit line to the material. If material is not included in the article's Creative Commons licence and your intended use is not permitted by statutory regulation or exceeds the permitted use, you will need to obtain permission directly from the copyright holder. To view a copy of this licence, visit http://creativecommons.org/licenses/by/4.0.

Publisher's Note Springer Nature remains neutral with regard to jurisdictional claims in published maps and institutional affiliations.

The original article can be found online at https://doi.org/10.1007/s10739-021-09639-4.

Pierre Louis Blaiseau

blaiseau.pierre@gmail.com

Allyson M. Holmes

allyson.holmes@ sorbonne-universite.fr

1 Sorbonne Université, CNRS, UMR7238, Institut de Biologie Paris-Seine, Laboratory

of Computational and Quantitative Biology, 75005 Paris, France 